\title{
INTEGRATED DISEASES MANAGEMENT (IDM) MODULES FOR THE MANAGEMENT OF COTTON DISEASES IN NATURAL CONDITION UNDER SOUTH GUJARAT REGION OF INDIA
}

\author{
Prashant B. SANDIPAN ${ }^{1 *}$, R.K. PATEL ${ }^{1}$, G.O. FALDU ${ }^{1}$, D.M. PATEL ${ }^{1}$ \\ *E-mail: prashantsandipan@gmail.com
}

Received: Sept. 19, 2019. Revised:Nov. 06, 2019. Accepted: Nov. 15 , 2019. Published online: Dec. 20, 2019

\begin{abstract}
Cotton is a vital commercial crop in the world and plays an important role for fibre, fuel and edible oil in the community and to industry. Cotton is a white fibrous agricultural product that has a wide variety of uses, from textile production, to creating paper, to producing oil and food products. Cotton is grown all around the globe, and is traded internationally as well. The cotton diseases scenario has shown a continuous change during the past 64 years. Several diseases have been reported for the cotton crop. The use of IDM strategy is gaining momentum now a days, but in developing countries it often lacks the enabling environment for its successful implementation. Cotton crop is affected by various diseases caused by organisms, such as fungi, bacteria and viruses that grow on and within the plant tissues. In this experiment, total seven modules including the control was tested in this experiment from which, module $6(6.50 \%$ PDI $)$, followed by module $5 \quad(8.50 \%$ PDI $)$ significantly recorded minimum bacterial
\end{abstract}

leaf blight infection in comparison to the module 7, i.e. control (18.50\% PDI) in RCH 2 BG II hybrid. For Alternaria leaf spot disease, module 6 (2.50\% PDI) were recorded significantly minimum Alternaria leaf spot disease in RCH 2 BG II hybrid, as compared to the control (10.50\% PDI), followed by module 5 (4.50\% PDI) and module 4 (5.50 \% PDI).

Keywords: cotton; Integrated Disease Management; biocontrol; modules.

\section{INTRODUCTION}

Cotton is grown all around the globe, and is traded internationally as well. Cotton is a white fibrous agricultural product that has a wide variety of uses, from textile production, to creating paper, to producing oil and food products. Plant diseases are measured as an important biotic constraint, which significantly leads to crop losses worldwide.

\footnotetext{
${ }^{1}$ Main Cotton Research Station (MCRS), Navsari Agricultural University (NAU), Surat, (Gujarat), India
} 


\section{ASCERTAIN INTEGRATED DISEASES MANAGEMENT IN COTTON CROP}

Integrated disease management (IDM), which combines physical, biological, cultural and chemical control strategies in a holistic way rather than using a single component strategy. In practice and in the majority of cropping systems today, emphasis is still being placed on a single technology. Nevertheless, the use of IDM strategy is gaining ground nowadays, but in developing countries it often lacks the enabling environment for its successful implementation. Cotton crop is affected by various diseases caused by organisms, such as fungi, bacteria and viruses that grow on and within the plant tissues. These organisms often cause stunting of the plants, defoliation, reduced vigor and yield and sometimes death. Out of 30 diseases known to occur in cotton crop from time to time, the bacterial blight is the most wide spread and destructive disease, reported to cause yield losses of about 10 to 30 per cent (Bhatti and Bhutta, 1983, Kalpana et al., 2004, Sekhon et al., 2008 and Sandipan et al., 2016).

However, wide adoption of IDM practices is a pre-requisite for achieving impact at the country level. Experience over the last few decades clearly showed that adoption and support for using participatory approaches help farmers improve their overall field management, including disease management, reducing costs and improving production efficiency. It is estimated that $10-15 \%$ of the already low yields in developing countries is lost due to disease attack, and losses can be higher if post harvest diseases are considered. This is a significant loss, considering that in developing countries at present more than 800 million people do not have enough food, and around 1.3 billion live on less than one dollar a day (FAO, 2004). Even though the use of IDM strategy is well established and results obtained are encouraging, in practice and in the majority of cropping systems today, emphasis is still being placed on a single technology, may it be host-plant resistance, pesticide applications or cultural practices and rarely the combination of all (Thomas and Waage, 1996). Considering this whole scenario, this present investigation was made to ascertain IDM in cotton crop.

\section{MATERIAL AND METHODS}

The experiment was laid by dibbling method with the following experimental details (Tables 1 and 2). All the recommended agronomic practices were followed for raising the good crop. In each net plot of each treatment randomly tag five plants and score five lower and five middle leaves of each plant in terms of 0-4 grade and work out PDI, as mentioned below by using 0-4 scale, as given by Sheoraj and Verma, 1988 and then these grades were converted into per cent disease incidence (PDI) by using the formula given by Wheeler, 1969 (Bacterial leaf blight and Alternaria leaf spot diseases). 


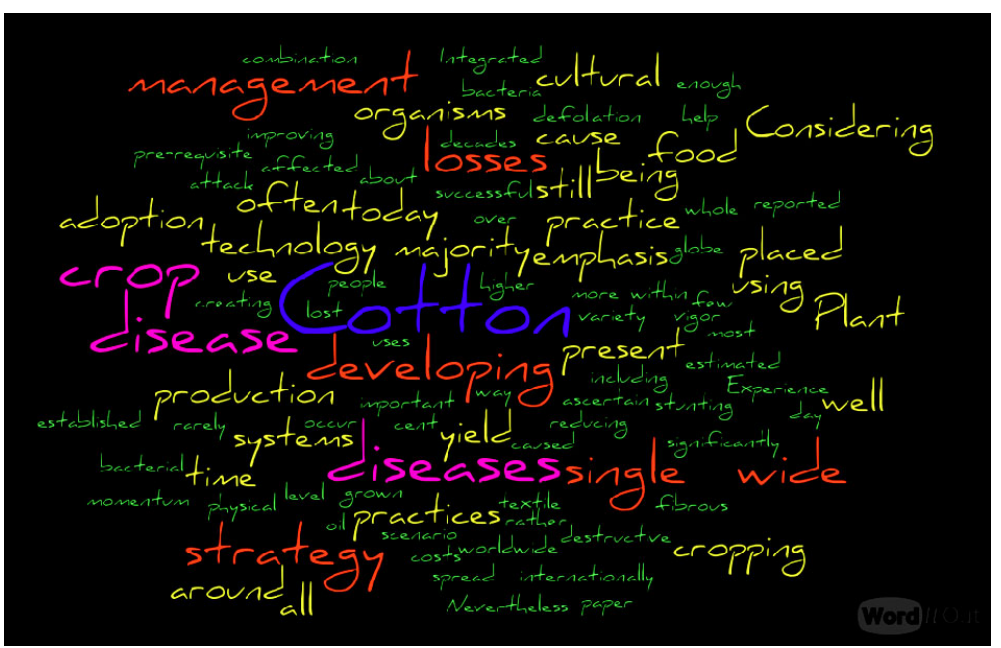

Word cloud from Introduction

Disease incidence $(\%)=\frac{\text { No. of infected plants }(\text { Numerical grades) }}{\text { No. of leaves observed } \times \text { Max. grades }} \times 100$

\begin{tabular}{ll}
\hline Score & Description \\
\hline 0 & DF = Immune, completely free from bacterial blight \\
\hline 1 & $\begin{array}{l}\mathrm{R}=\text { Resistant, nearly } 1 \mathrm{~mm} \text { in diameter, not coalescing, reddish, not } \\
\text { angular, veins free (spots few scattered) }\end{array}$ \\
\hline 2 & $\mathrm{MR}=$ Moderately resistant, leaf area covered up to $10 \%$ \\
\hline 3 & $\mathrm{MS}=$ Moderately susceptible, leaf area covered up to $11-20 \%$ \\
\hline 4 & $\mathrm{~S}=$ Susceptible, leaf area covered more than $20 \%$ \\
\hline
\end{tabular}

For Bacterial leaf blight (BLB) disease

\begin{tabular}{ll}
\hline Score & Description \\
\hline 0 & No infection, completely free from the infection \\
\hline 1 & Few < 2mm, scattered, brown spots, leaf area covered <5 \\
\hline 2 & $\begin{array}{l}\text { Spots bigger, } 3 \mathrm{~mm}, \text { not coalescing, brown and 6-20\% leaf area } \\
\text { covered }\end{array}$ \\
\hline 3 & $\begin{array}{l}\text { Spots, } 3-5 \mathrm{~mm}, \text { irregular in shape coalescing, 21-40\% leaf area } \\
\text { covered }\end{array}$ \\
\hline 4 & $\begin{array}{l}\text { Spots coalescing to form bigger lesions, irregular }>40 \% \text { leaf area } \\
\text { covered }\end{array}$ \\
\hline
\end{tabular}

For Alternaria leaf spot (ALS) disease

For Alternaria disease, it is standard methodology of AICCIP, cotton and similar disease scale was used by Anil (2013) in his thesis on Studies on leaf blight of Bt cotton, caused by Alternaria spp. in 2013, submitted to the University of Agricultural Sciences (Hosagoudar et al., 2008 a,b). 


\section{ASCERTAIN INTEGRATED DISEASES MANAGEMENT IN COTTON CROP}

Table 1 - Experimental details

\begin{tabular}{|c|c|c|c|}
\hline 1 & Objective & $:$ & $\begin{array}{l}\text { To find out the effective module for the } \\
\text { management of cotton diseases. }\end{array}$ \\
\hline 2 & Location & $:$ & Main Cotton Research Station, Surat \\
\hline 3 & Year of commencement & $:$ & kharif, 2016 \\
\hline 4 & Experimental details & & \\
\hline$a$ & Design & $:$ & R.B.D. \\
\hline b & Treatment & : & $6+1$ Control \\
\hline $\mathrm{c}$ & Replication & : & 3 \\
\hline d & Plot size in $\mathrm{mts}$ & $:$ & $\begin{array}{l}\text { Gross: } 3.6 \times 6.0 \\
\text { Net: } 2.7 \times 3.6\end{array}$ \\
\hline $\mathrm{e}$ & No. of varieties/treatment & $:$ & Bt hybrid (RCH 2 BG II) \\
\hline$f$ & No. of rows/plot & $:$ & - \\
\hline g & No. of dibbles/row & : & 08 \\
\hline $\mathrm{h}$ & Plot size in $\mathrm{m}^{2}$ (1 plot) & $:$ & 21.6 \\
\hline $\mathrm{i}$ & Expt. area in ha & $:$ & 0.05 \\
\hline j & Spacing & $:$ & $120 \times 45 \mathrm{~cm}$ \\
\hline $\mathrm{k}$ & FYM t/ha & $:$ & - \\
\hline $\mathrm{I}$ & Fertilizer dose NPK kg/ha & $:$ & 240:40:00 \\
\hline $\mathrm{m}$ & Previous crop & : & Sunhemp (green manuring) \\
\hline $\mathrm{n}$ & Date of sowing & $:$ & 08.07 .16 \\
\hline 0 & Date of germination & $:$ & - \\
\hline$p$ & Date of gap filling & $:$ & 19.07.16 \\
\hline$q$ & No. of plant protection & : & As per the treatments \\
\hline$r$ & No. of irrigation & $:$ & As \& when required \\
\hline $\mathrm{t}$ & Date of harvesting & : & - \\
\hline
\end{tabular}

Table 2 - Treatment details

\section{Trt. No. Treatment Details}

ST - Trichoderma viride (TV-TNAU) @ $10 \mathrm{~g} / \mathrm{kg}$ of seed + SA @ $2.5 \mathrm{~kg}$

$\mathrm{T}_{1} \quad$ developed in $250 \mathrm{~kg}$ FYM or vermicompost/ ha and foliar spray with $T$. viride (a) $1 \%$

ST - Bacillus subtilis (BSC5-TNAU ) @ $10 \mathrm{~g} / \mathrm{kg}$ of seed + SA @ $2.5 \mathrm{~kg}$

$\mathrm{T}_{2}$ developed in $250 \mathrm{~kg} \mathrm{FYM}$ or vermicompost/ha and foliar spray with $B$. subtilis @ $1 \%$

T ST - Pseudomonas fluorescens ( PF-TNAU ) + SA @ $2.5 \mathrm{~kg}$ developed in $250 \mathrm{~kg}$ FYM or vermicompost/ha and foliar spray with $P$. fluorescens @ 1\% ST - PF CICR @ $10 \mathrm{~g} / \mathrm{kg}$ of seed + Soil Application - Pseudomonas

$\mathrm{T}_{4} \quad$ fluorescens - PF CICR @ $2.5 \mathrm{~kg} / \mathrm{ha}$ in $250 \mathrm{~kg}$ of Compost or FYM and foliar spray with Pseudomonas fluorescens $1 \%$ - PF

ST - PF CICR @ $10 \mathrm{~g} / \mathrm{kg}$ of seed + Soil Application of Trichoderma viride @

$\mathrm{T}_{5} \quad 2.5 \mathrm{~kg} / \mathrm{ha}$ TV-TNAU1 FS with propiconazole $0.1 \%$ for fungal diseases and COC $(0.3 \%)+$ Streptocycline $(0.01 \%)$ for BLB or Carbendazim $0.1 \%$ for grey mildew on need basis

ST - PF CICR @ $10 \mathrm{~g} / \mathrm{kg}$ of seed + Soil Application of Trichoderma viride @

$\mathrm{T}_{6} \quad 2.5 \mathrm{~kg} / \mathrm{ha}$ TV- TNAU1 in $250 \mathrm{~kg}$ of Compost or FYM and foliar spray with Kresoxim methyl @ 1 ml/litre, followed by Captan + Hexaconazole @ 1.5 $\mathrm{g} /$ litre for fungal diseases or COC $(0.3 \%)+$ Streptocycline $(0.01 \%)$ for BLB

$\mathrm{T}_{7} \quad$ Control 


\section{RESULTS AND DISCUSSION}

The field experiment was conducted during kharif 2016. The results presented in Table 3 and Fig. 1 revealed that the out of the total seven modules, including the control, module $6(6.50 \% \mathrm{PDI})$, followed by module 5 ( $8.50 \%$ PDI), significantly recorded minimum bacterial leaf blight infection in comparison to the module 7 , i.e. control (18.50\% PDI) in RCH 2 BG II hybrid, while all the remaining modules found statistically at par with the module 7 , i.e. control for the bacterial leaf blight at Surat centre (Main Cotton Research Station).

For Alternaria leaf spot disease, module $6(2.50 \%$ PDI) were recorded significantly minimum

Alternaria leaf spot disease in RCH 2 BG II hybrid, as compared to the control (10.50\% PDI), followed by module 5 (4.50\% PDI) and module 4 (5.50\% PDI) (Table 3 and Fig. 2).

The highest seed cotton yield was recorded in module 6
$(2690.00 \mathrm{~kg} / \mathrm{ha})$, followed by module 5 $(2430.67 \mathrm{~kg} / \mathrm{ha})$ and module 4 (2311.00 kg/ ha) (Fig. 3).

Comparison of the efficacy between the biocontrol agents used in different modules at Surat centre indicated that module 6 (ST - PF CICR@ 10 g/kg of seed + Soil Application of Trichoderma viride (a) $2.5 \mathrm{~kg} / \mathrm{ha}$ TV-TNAU1 in $250 \mathrm{~kg}$ of Compost or FYM and foliar spray with Kresoxim methyl@1 ml/litre, followed by Captan + Hexaconazole (a) $1.5 \mathrm{~g} /$ litre for fungal diseases or COC $(0.3 \%)+$ Streptocycline $(0.01 \%)$ for BLB) and module 5 (ST - PF CICR@10 g/kg of seed + Soil Application of Trichoderma viride (a) $2.5 \mathrm{~kg} / \mathrm{ha}$ TV-TNAU1 FS with Propiconazole $0.1 \%$ for fungal diseases and $\mathrm{COC} \quad 0.3 \%+$ Streptocycline $0.01 \%$ for BLB or Carbendazim $0.1 \%$ for grey mildew on need basis) were found effective in reducing the bacterial leaf blight and Alternaria leaf spot diseases in RCH 2 BG II hybrid cotton.

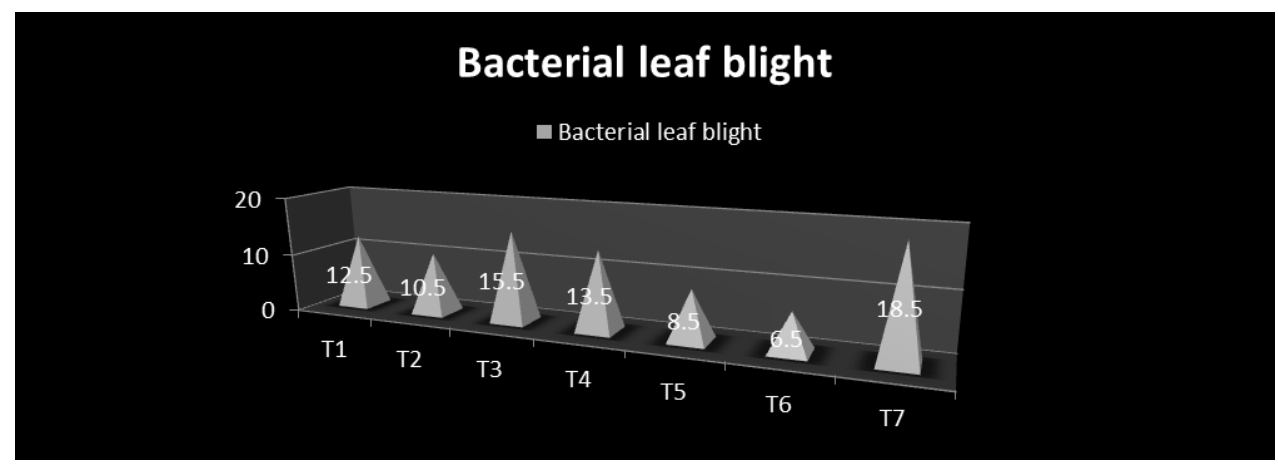

Figure 1 - Per cent disease intensity of Bacterial leaf blight (BLB) 
Table 3 - Statement showing the per cent disease intensity of Bacterial leaf blight (BLB) and Alternaria leaf spot (ALS) and seed cotton yield in Developing IDM modules for the management of cotton diseases 2016-17

\begin{tabular}{|c|c|c|c|c|}
\hline $\begin{array}{l}\text { Sr. } \\
\text { No. }\end{array}$ & Treatment & $\begin{array}{l}\text { Bacterial } \\
\text { leaf } \\
\text { blight } \\
\text { (PDI) }\end{array}$ & $\begin{array}{l}\text { Alternaria } \\
\text { leaf spot } \\
\text { (PDI) }\end{array}$ & $\begin{array}{l}\text { Seed } \\
\text { cotton } \\
\text { yield } \\
\text { (kg/ha) }\end{array}$ \\
\hline $\mathbf{T}_{1}$ & $\begin{array}{l}\text { ST - Trichoderma viride (TV-TNAU) @ } 10 \\
\mathrm{~g} / \mathrm{kg} \text { of seed + SA @ } 2.5 \mathrm{~kg} \text { developed in } \\
250 \mathrm{~kg} \text { FYM or vermicompost/ha and foliar } \\
\text { spray with T. viride @ } 1 \%\end{array}$ & $\begin{array}{c}12.50 \\
(20.60)^{*}\end{array}$ & $\begin{array}{c}6.50 \\
(14.58)^{*}\end{array}$ & 2118.67 \\
\hline$T_{2}$ & $\begin{array}{l}\text { ST - Bacillus subtilis (BSC5-TNAU) @ } 10 \\
\text { g/kg of seed + SA @ } 2.5 \text { kg developed in } \\
250 \text { kg FYM or vermicompost/ha and foliar } \\
\text { spray with B. subtilis @ 1\% }\end{array}$ & $\begin{array}{c}10.50 \\
(18.79)\end{array}$ & $\begin{array}{c}8.00 \\
(16.23)\end{array}$ & 2048.33 \\
\hline$T_{3}$ & $\begin{array}{l}\text { ST - Pseudomonas fluorescens (PF- } \\
\text { TNAU) + SA @ } 2.5 \mathrm{~kg} \text { developed in } 250 \mathrm{~kg} \\
\text { FYM or vermicompost/ha and foliar spray } \\
\text { with P. fluorescens @ } 1 \%\end{array}$ & $\begin{array}{c}15.50 \\
(23.11)\end{array}$ & $\begin{array}{c}9.00 \\
(17.16)\end{array}$ & 1915.00 \\
\hline$T_{4}$ & $\begin{array}{l}\text { ST - PF CICR @ } 10 \mathrm{~g} / \mathrm{kg} \text { of seed + Soil } \\
\text { Application - Pseudomonas fluorescens - } \\
\text { PF CICR @ } 2.5 \mathrm{~kg} / \mathrm{ha} \text { in } 250 \mathrm{~kg} \text { of } \\
\text { Compost or FYM and foliar spray with } \\
\text { Pseudomonas fluorescens } 1 \% \text { - PF }\end{array}$ & $\begin{array}{c}13.50 \\
(21.42)\end{array}$ & $\begin{array}{c}5.50 \\
(13.22)\end{array}$ & 2311.00 \\
\hline $\mathbf{T}_{5}$ & $\begin{array}{l}\text { ST - PF CICR @ } 10 \mathrm{~g} / \mathrm{kg} \text { of seed + Soil } \\
\text { Application of Trichoderma viride @ } 2.5 \\
\mathrm{~kg} / \mathrm{ha} \text { TV-TNAU1 FS with Propiconazole } \\
0.1 \% \text { for fungal diseases and COC }(0.3 \%) \\
+ \text { Streptocycline }(0.01 \%) \text { for BLB or } \\
\text { Carbendazim } 0.1 \% \text { for grey mildew on } \\
\text { need basis }\end{array}$ & $\begin{array}{c}8.50 \\
(16.82)\end{array}$ & $\begin{array}{c}4.50 \\
(11.98)\end{array}$ & 2430.67 \\
\hline $\mathrm{T}_{6}$ & $\begin{array}{l}\text { ST - PF CICR @ } 10 \mathrm{~g} / \mathrm{kg} \text { of seed + Soil } \\
\text { Application of Trichoderma viride @ } 2.5 \\
\mathrm{~kg} / \mathrm{ha} \text { TV- TNAU1 in } 250 \mathrm{~kg} \text { of Compost or } \\
\text { FYM and foliar spray with Kresoxim methyl } \\
@ 1 \mathrm{ml} / \mathrm{litre} \text {, followed by Captan + } \\
\text { Hexaconazole @ } 1.5 \mathrm{~g} / \mathrm{litre} \text { for fungal } \\
\text { diseases or COC }(0.3 \%)+\text { Streptocycline } \\
(0.01 \%) \text { for BLB }\end{array}$ & $\begin{array}{c}6.50 \\
(14.67)\end{array}$ & $\begin{array}{c}2.50 \\
(8.78)\end{array}$ & 2690.00 \\
\hline $\mathbf{T}_{7}$ & Control & $\begin{array}{c}18.50 \\
(25.41)\end{array}$ & $\begin{array}{c}10.50 \\
(18.76)\end{array}$ & 1710.00 \\
\hline \multicolumn{2}{|c|}{ S.Em. \pm} & 1.37 & 1.86 & 131.35 \\
\hline \multicolumn{2}{|c|}{ C.D. at $5 \%$} & 4.23 & 5.73 & 404.75 \\
\hline \multicolumn{2}{|c|}{ C.V. \% } & 11.82 & 22.38 & 10.46 \\
\hline \multicolumn{2}{|c|}{$\mathrm{Y} \times \mathrm{T}$} & * & * & * \\
\hline
\end{tabular}




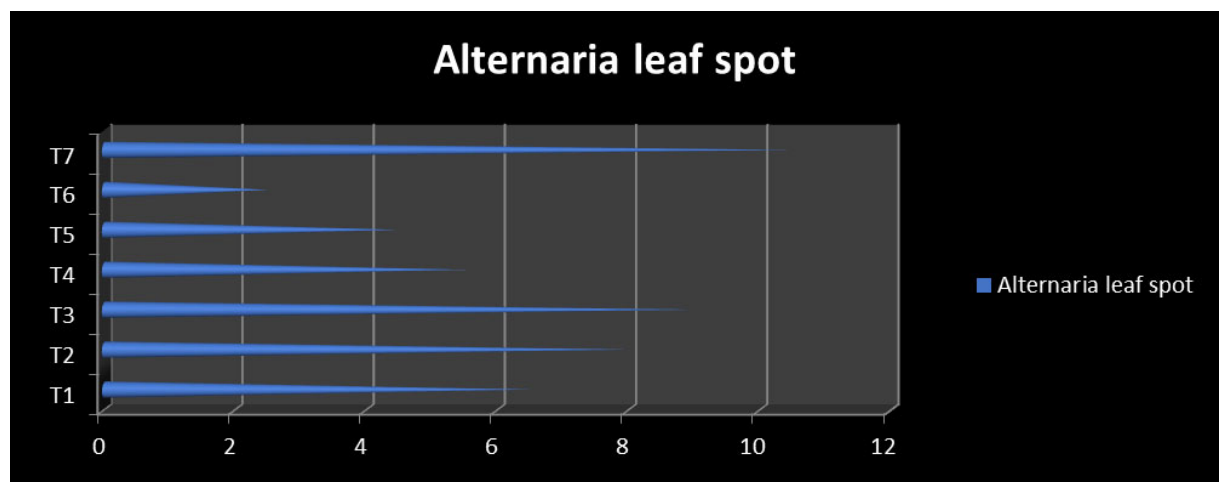

Figure 2 - Per cent disease intensity of Alternaria leaf spot (ALS)

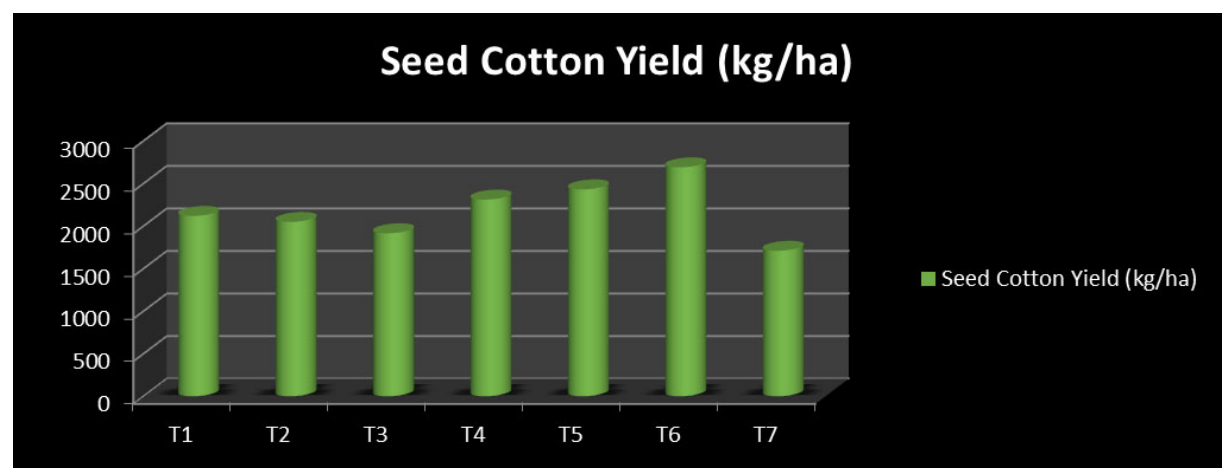

Figure 3 - Seed cotton yield

\section{CONCLUSIONS}

It is originate from the module 6, which consists of Seed treatment of PF CICR@10 g/kg of seed + Soil Application of Trichoderma viride (a) $2.5 \mathrm{~kg} / \mathrm{ha}$ TV-TNAU1 in $250 \mathrm{~kg}$ of Compost or Farm yard manure (FYM) and foliar spray with Kresoxim methyl@1 ml/litre, followed by Captan+Hexaconazole@1.5 g/litre for fungal diseases or COC $(0.3 \%)+$ Streptocycline $(0.01 \%)$ was found effective in plummeting the bacterial leaf blight disease in cotton crop.
Acknowledgement. Author is highly thankful to Main Cotton Research Station (MCRS), NAU, Surat (Gujarat) for providing the required facility and other arrangements for the conducting the experiment.

\section{REFERENCES}

Anil, G.H. (2013). Studies on leaf blight of Bt cotton caused by Alternaria spp. M.Sc. thesis submitted to the University of Agricultural Sciences, Dharwad, Karnataka State, India.

Bhatti, M.A.R. \& Bhutta, A.R. (1983). Incidence of seed borne bacterial infection in different cultivars of cotton. Pakistan Cottons, 27: 73-74. 


\section{ASCERTAIN INTEGRATED DISEASES MANAGEMENT IN COTTON CROP}

FAO (2004). FAOSTAT: FAO statistical data bases. Rome, Italy (http://faostat.fao.org).

Hosagoudar, G.N., Chattannavar, S.N. \& Kulkarni, S. (2008a). Screening of $\mathrm{Bt}$ and non Bt cotton genotypes for foliar diseases. Karnataka J.Agric. Sci., 21(1): 141-143.

Hosagoudar, G.N., Chattannavar, S.N. \& Kulkarni, S. (2008b). Survey for foliar diseases of $\mathrm{Bt}$ cotton. Karnataka J.Agric.Sci., 21(1): 139140.

Kalpana, P., Chellamuthu, V. \& Jeyalakshmi, C. (2004). Screening of cotton hybrids against bacterial blight incited by Xanthomonas campestris pv. malvacearum (Smith) Dye, Paper presented in Inter. Symp. Strat. Sust. Cotton Prod. - A Global Vision 3, Crop Production, 23-25 Nov. 2004, Univ. Agric. Sci. Dharwad (India), pp. 373-374.

Sandipan, B. Prashant, Desai, H.R. \& Solanki, B.G. (2016). Cotton pathology. In: Cotton Research in Gujarat, Technical Bulletin,
University publication No.88/201516, p. 100, Research Scientist (Cotton), MCRS, NAU, Surat (Gujarat).

Sheoraj \& Verma, J.P. (1988). Diseases of cotton in India and their management. Trop. Plant Pathol., 5: 207-254.

Sekhon, P.S., Singh, D. \& Singh, G. (2008). Cotton pathology research achievements and targets in Punjab. All India Coordinated Cotton Improvement Project Report. PAU, Ludhiana.

Thomas M. \& Waage J. (1996). Integration of biological control and host-plant resistance breeding: a scientific and literature review. Technical Center for Agriculture and Rural Cooperation of the European Union, Wageningen, The Netherlands.

Wheeler, B.E.J. (1969). An introduction to plant diseases. John Wiley \& Sons Ltd., London, $374 \mathrm{pp}$. 